\title{
GLOBAL FINANCIAL CRISES AND ECONOMIC GROWTH : EVIDENCE FROM EAST ASIAN ECONOMIES ${ }^{1}$
}

\author{
Arisyi F. Raz ${ }^{2}$, Tamarind P. K. Indra ${ }^{3}$, Dea K. Artikasih ${ }^{4}$, and Syalinda Citra ${ }^{5}$
}

\begin{abstract}
As economies become more integrated in the midst of globalization, financial crisis that occurs in one country can easily transmit to other countries, becoming global financial catastrophe in a short period of time. In such event, strong economic fundamentals are particularly important to defend a country from the contagious effect of the crisis. As evidence, due to the fragile economic fundamentals and lacking government credibility, East Asian economies were easily attacked by the crisis in 1997 once the sentiment deteriorated. Nevertheless, the region had learned its lessons in 1997 thereby proofing its resilience in facing the global financial crisis that struck in 2008 by improving its economic fundamentals as well as policymakers' credibility. This paper starts with theories on economic growth and financial crisis. Further, it empirically examines to what extent the financial crises in 1997 and 2008 affect East Asian economies by using panel data econometrics. The evidence shows that, even though both crises have contributed adverse impacts on East Asian economies, the magnitude of the 2008 crisis was relatively less severe than that in 1997. Finally, this study also provides further discussions regarding how East Asian economies had successfully minimized the impact of the global crisis in 2008.
\end{abstract}

Keywords: Global Financial Crises; East Asian Economies; Economic Growth;Financial Market; Random and Fixed Effects

JEL Classification: C330, E440, G010

\footnotetext{
1 Authors are extremely grateful for the helpful comments from Andi M.A. Parewangi. A previous version of this paper was presented at the $6^{\text {th }}$ Annual Workshop Bulletin of Monetary Economics and Banking, Jakarta, September 6, 2012.

2 Graduate of Institute for Development Policy and Management, University of Manchester.

3 Graduate student at Graduate School of Business of Economics, University of Melbourne.

4 Alumni of Department of Business and Asian Studies, Griffith University.

5 Graduate student at Faculty of Economics and Business, University of Indonesia.
} 


\section{INTRODUCTION}

Since the globalization era, the occurrence of financial crises has become more frequent than before. One of the main reasons is the advancement in information technology, which, to some extent, enlarges the magnitude of the crisis and acceleratesits spread to other regions or countries. Another reason is the rapid development of financial sector. One of the examples is the emergence of the so-called International Financial Integration (IFI). In this regard, Edison et al. (2002) explain that IFI refers to as "the degree to which an economy does not restrict crossborder transactions" (page 1). Hence, due to the integrated financial systems, the occurrence of localized financial nuisance in one country can result in a domino effect by perplexing other integrated economies, leading to a global financial havoc.

In the last two decades, at least two major financial crises occurred, namely the 1997 East Asian Financial Crisis and the 2008 Global Financial Crisis. While the crisis in 1997 was due to the lack of government transparency and credibility that led to structural and policy distortions (see e.g. Corsetti et al., 1999), the economic turmoil in 2008 was mainly triggered by the rapid innovation in financial products such as securitization practices and credit default swaps. It was undermined further by property speculation and inaccurate credit ratings. In both cases, the development of the crises spread to other regions and, in a short period, became global crises due to the contagious effects amid globally integrated financial systems and rapid information sharing.

Even though the sources of the crises may be varied, the consequences of financial crises have always been associated with macroeconomic indicators, particularly economic growth. For instance, during the East Asian crisis, East Asia plunged from being the fastest growing region in the world to the region which several countries recorded negative income growth in 1998 such as Indonesia, Malaysia, Singapore, South Korea, Philippines and Thailand (Asian Development Bank, 1999, Table A2). Later, Indonesia, Thailand and South Korea had to go to the International Monetary Fund (IMF) for large bailout loan programs. On the other hand, during the 2008 crisis, even though the source of crisis was due to the collapse of international financial institutions in the west, especially those in the US and UK, some of East Asian countries such as Malaysia, Singapore and Thailand were also dragged to the crisis by experiencing huge financial encumbrance. Nevertheless, statistics shows that the impact of the crisis in 2008on East Asian countries was not as deep as that in 1997. In addition, these countries managed to recover rapidly. In this regard, many argue that East Asian countries have learned their lessons in 1997 and endured the crisis in 2008 through fortified economic fundamentals.

Given these facts, it has become more important to conduct formal examination vis-à-vis the causes and consequences of financial crises, particularly in the context of East Asian region. Hence, the objective of this paper is to measure the impact of each financial crisis on economic growth in East Asian economies. Further, it is also important to analyze how East Asian economies managed to minimize the impact of 2008 Global Financial Crisis. Until now,even though there 
are already vast amount of literature analyzing the impact of the 1997 East Asian Financial Crisis, most of these studies use the qualitative approach (for instrance, see Corsetti et al., 1999; Lloyd and MacLaren, 2000; Jomo, 2001). In addition, due to its recent occurrence, the study that examines the consequences of the $2008 \mathrm{Global}$ Financial Crisis is also limited. Hence, this paper aims to fill the gap in the literature by introducing a quantitative methodology and comparing the consequences of both crises in East Asian economies. The rest of this paper is organized as follows: Section 2 reviews the related theories on economic growth and financial crises; Section 3 provides some methodology to measure the impact of both financial crises on growth by using econometric modeling; Section 4 presents the empirical evidence and further dicussions, and Section 6 concludes the paper.

\section{THEORY}

\section{Growth Theories}

Since the aim of this paper is to examine the impact of financial crises on economic growth, firstly, it is necessary to derive the factors of growth from theoretical perspective. This section, thus, introduces several growth theories that can be applied for the purpose of methodology. According to the neoclassical view (e.g. Solow, 1956), growth is underpinned by capital accumulation, which diminishes in the long run. As the consequence, a country will reach its "steady-state" in the long run, i.e. zero economic growth. One of the implications of this growth model is that the less developed countries with open economies may eventually catch up with developed countries as capital flows from the rich to poor countries that can offer higher returns on investment, resulting in economic convergence (Todaro and Smith, 2006).

On the other hand, the so-called "new growth theories" contradict this theory by suggesting that a country does not necessarily experience "steady-state" in the long run. For instance, a study by Lucas (1988) considers human capital as an endogenous variable of growth and suggests that there are no diminishing returns to the combination of the accumulation of human capital and capital goods, i.e. there is growth in the long run. These constant returnsto scale are caused by the positive externality effects of knowledge, which affect the output of individual firms in the economy. Another theory is proposed by Romer (1986, 1990), which urges the importance of science and technology as the engine of economic growth. He argues that there are capital spillovers created by firms, which, in turn, create knowledge. Knowledge, which triggers positive externalities, will prevent growth to diminish in the long run.

In application, human capital and knowledge spillovers can be obtained through FDI and, to lesser extent, trade. In the scope of developing world, Yao and Wei (2007) argue that FDI can act as a means to transfer these factors from developed countries to developing countries since FDI accelerates the speed of General Purpose Technology ${ }^{6}$ (GPT) and introduces advanced

6 General Purpose Technologies are technologies that have impact on the whole national economy, such as computer and automobile. 
technologies and know-how that do not exist in the developing countries. Developing countries, thus, will utilise these factors as assets in order to enhance economic growth. Some literature, however, suggest that FDI can distribute knowledge and know-how efficiently to a country only if it meets several conditions. For instance, a hypothesis by Bhagwati (1994) points out that trade policy plays a crucial role in determining the effectiveness of FDI in distributing positive externalities in the country. In this regard, he argues that country with export orientation can capture the spill over effects of FDI more efficiently and, thus, will have higher growth rate.

In short, this section shows that, based on the neoclassical growth theory, initial income is an important factor of growth since countries with relatively lower initial income will grow faster and catch up with those with higher initial income. Further, it also points out that capital accumulation acts as the engine of growth in the short run. Meanwhile, new growth theories argue that variables such as FDI and trade are also important in creating sustainable economic growth in the long run by creating positive externalities through transfer of knowledge. Hence, for the purpose of methodology, these variables are considered as the main determinants of growth. Before proceeding to the methodology, however, this paper will first investigate the typology of financial crises in the following section.

\section{Typology offinancial Crisis}

The Reserve Bank of Australia (2012) defines a stable financial system as the one in which any activities of fund transfer from lenders to borrowers are being well accommodated by financial intermediaries, market, and market structure. Financial instability, therefore, is a condition where a collapse in financial system disrupts these activities and triggersa financial crisis. Indeed systemic risks are always attached to any financial system, which according to Davis (2001) is closely related to the wealth and soundness financial institutions. In other cases, failure of market liquidity and breakdown of market infrastructure may also initiate the risks.

In his paper, Davis (2001) also outlines several theoretical framework that explain financial instability, which include: 1)the debt and financial fragility theory, 2) disaster myopia theory, and 3) bank runs theory. The debt and financial fragility theory argues that the economy follows a cycle that consists of period of positive and negative growth (Fisher, 1933). With the upturn of the economy, debt and risk taking activities increases. These create an asset bubble that will lead to negative growth. Meanwhile, disaster myopia theory suggests that financial instability may be caused bycompetitive behaviour of financial institutions that lead to a condition where the credibility of borrowers were neglected and risks were undermined (Herring, 1999). On the other hand, the bank runs theory explains the condition in which panic investors sell their assets or drawdown their funds for fear that economic condition will be worsened (Diamond and Dybvig, 1983; Davis, 1994). As the consequence, this will lead to a sudden plunge in asset prices and liquidity crisis. 
To their own extent, all of these three theories may explain the 1997 East Asian Financial Crisis. Financial deregulations with inadequate regulatory supervision caused the asset bubble that led to negative economic growth in East Asian economies. Meanwhile, the can rapid expansion can also lead to credit crunch since credits were channelled recklessly to insolvent borrowers in order to increase profitability. Last but not least, when investors realized that the situation was already bad, they withdrew their funds, leading to massive capital outflows.

In addition to these basic theories, some literature suggest that financial instability can also be caused by the role of international capital flows through international transmission, such as trade patterns, exchange rate pressure and foreign investment, which causes the "contagious effect" (see e.g. Chongvilaivan, 2010; Glock and Rose, 1998; Davis, 2001). For instance, the Global Financial Crisis that occurred in 2008 was actually triggered by the Subprime mortgage crisis originated in the US. Even though the crisis in the US can be explained by the above theories, its spread to other regions, including East Asian region, was attributed to the contagious effect of the Sub-prime mortgage crisis.

\section{METHODOLOGY}

This section provides research methodology in examining the impact of financial crises in 1998 and 2008 on East Asian economies. This paper collects data from World Bank's World Development Indicators (WDI) dataset for the period of 1990-2010. It obtains various macroeconomic variables of the selected East Asia economies, including the ASEAN-5 (Indonesia, Malaysia, the Philippines, Singapore, and Thailand) and other notable East Asian economies, i.e. China, Japan and South Korea.

In order to examine the relationship between economic growth and financial crisis, it is necessary to develop the growth determinants first. By following the previous studies (for instance, seeBarro, 2001; Chongvilaivan, 2010), growth is determined as a function of initial income, capital expenditure, investment, and trade. Then, this benchmark growth model is augmented with the crisis dummy. As the result, this paper defines the empirical framework as follows:

$$
\text { Growth }_{i t}=\beta_{0}+\beta_{1} \text { Income }_{i t}+\beta_{2} \text { Capital }_{i t}+\beta_{3} F D I_{i t}+\beta_{4} \text { Trade }_{i t}+\beta_{5} \text { Crisis }_{i t}+\varepsilon
$$

where the subscripts $i, i=1,2, \ldots, N$, and $t, t=1,2, \ldots, T$, denote an economy $i$ at the time period $t$, respectively.

The dependent variable, Growth, is the GDP per capita growth rate. The firstexplanatory variable, Income, is the logarithmic form of GDP per capita. Next, Capital is the gross fixed capital formation as a percentage of GDP, which is included in order to capture the countryspecific productivity levels (Siegel and Griliches, 1992; Siegel, 1997). The rationale is that, higher portion of capital accumulation leads to higher productivity level, thus increasing income 
growth. FDI is the net foreign direct investment as a percentage of GDP. To some extent, the role of FDI in contributing to growth is similar but not limited to that of capital. The reason is because FDI also facilitates externalities and spillover effects, which enhance further the efficiency of productivity of local firms (for instance, see Lim, 2001; Yao and Wei, 2007). Trade is a proxy of international trade openness, which is measured by the ratio of exports and imports to GDP. Chongvilaivan (2010) suggests that this variable represents the impacts of the global financial crisis on an economy with respect to the commodity markets. Finally, a dummy variable, Crisis, is included in the model. It takes the value of unity during crisis period, i.e. the 1998 East Asian Financial Crisis and 2008 Global Financial Crisis, and zero otherwise. For more details about the variables, please refer to Appendix 1.

From this model, income is expected to have a negative sign. The rationale is based on the neo-classical Solow Swan model, which suggests that economies with lower income level will grow faster and catch up those with higher income level, resulting in income convergence (for instance, see Solow, 1956). On the other hand, capital and FDI are expected to have positive relationships with growth. While the neo-classical Solow-Swan model suggests that all type of capitals have similar role in contributing to economic growth, the "new growth theories" suggests otherwise. As mentioned earlier, through FDI, these externalities can be transferred from industrialised countries to the developing countries as important assets to enhance economic growth further (for instance, see Yao and Wei, 2007). Due to this reason, this paper expects the coefficient of FDI to be bigger compared to that of capital since it has bigger role in contributing economic growth.

The relationship between trade openness and income growth is more complex, depending on whether international trade causes trade creation or trade diversion. The former occurs when international trade increases the welfare of the members of trade alliance without sacrificing that of the non-members. On the other hand, the latter occurs when trade alliance is formed at the expense of its non-members and thus welfare-decreasing. In this regard, the relationship between trade openness and income growth depends on which of these influences has stronger effect.

Lastly, the coefficient of crisis dummy is expected to be negative, which is intuitive. Nevertheless, the coefficient of 1998 East Asian Financial Crisis is expected to be bigger than that of 2008 Global Financial Crisis since, as mentioned earlier, East Asian countries had stronger fundamentals and better resistance during the 2008 Global Financial Crisis.

Due to the panel nature of the data, this paper uses the fixed effects and random effects methods for the estimation purpose. By using fixed effects, the model controls for unobserved heterogeneity by assuming that each country has its own effects that may influence the dependent variable. In this model, each country's heterogeneity is captured by the intercept and associated with the independent variables. Thus, the nature of fixed effects prevents the estimation to suffer heterogeneous bias and thus the model always gives consistent results. The 
presence of fixed effects can be tested by conducting an F-test. The fixed effects are jointly significant when the null is significantly rejected. Another model is the random effects model, which assumes that the variation across countries is random and uncorrelated with the independent variables. Different from the fixed effects model, the presence of random effects can be tested by using a Breusch-Pagan Lagrange Multiplier test.

\section{RESULT AND ANALYSIS}

This section provides the estimation results of Equation (1). Nevertheless, before proceeding to the results, it is necessary to justify the stationarity of the variables included in the model. As shown earlier, this study utilizes data set that covers a long period, i.e. 21 years. Thus some variables may contain a unit root. If unit root is present, these variables become non-stationary and cause the traditional estimation methods cannot be used since they can result in a spurious regression. In this case, a test for cointegration is necessary for the non-stationary variables.

There are several panel unit root tests that can be performed such as Hadri (2000), Levin, Lin and Chu (2002) and Im, Pesaran and Shin (2003). In this regard, this paper employs the Levin, Lin and Chu (2002) to test the presence of unit root in the variables. The results confirm the stationarity of these variables since the null of a unit root is significantly rejected at the $5 \%$ level for all variables (Appendix 4). Therefore it is not necessary to do the cointegration test. Consequentially, Equation (1) can be estimated by using the fixed effects and random effects model.

In addition, due to the nature of the data, serial correlation and/or heteroscedasticity may present, which can lead to inconsistent and biased estimation results. Hence, this paper corrects these problems by treating each country effects as a cluster in order to estimate the correct standard errors with the Huber/White cluster-robust covariance estimator in all regressions.

\section{Benchmark Growth Regression}

The first column of Table 1shows the results of the fixed effects estimation, whereas the second column shows the results of random effects estimation. Overall, the results are consistent with economic theory and expectations. The first explanatory variable, income, is not significant in the first column but significant at $1 \%$ in the second column with negative coefficient.

Next, capital is significant in both columns, even though the magnitude is bigger in the random effects. Overall, despite the relatively higher magnitude, this result is consistent with the previous studies (for instance, see Chongvilaivan, 2010). Hence, it proves that higher capital accumulation results in higher productivity and enhances income growth.Further, FDI is also significant at $1 \%$ and positively correlated with income growth in both regressions. In the fixed effects model, according to expectation, the magnitude of FDI is bigger than capital, which is 
also consistent with the previous studies (for instance, see Stopford et al.,1991; Azman-Saini and Ahmad, 2010). However, contradicting the result in the fixed effects model, the random effects model shows that the coefficient of capital is slightly higher than that of FDI.

\begin{tabular}{|c|c|c|}
\hline \multicolumn{3}{|c|}{$\begin{array}{l}\text { Table } 1 . \\
\text { Benchmark Growth Regression }\end{array}$} \\
\hline Variables & Fixed Effects & Random Effects \\
\hline Constant & $\begin{array}{c}-14.575 \\
(6.982)\end{array}$ & $\begin{array}{c}-1.206 \\
(2.158)\end{array}$ \\
\hline Income & $\begin{array}{c}3.098 \\
(2.141)\end{array}$ & $\begin{array}{c}-1.274^{\star * *} \\
(0.417)\end{array}$ \\
\hline Modal & $\begin{array}{l}0.216^{\star *} \\
(0.068)\end{array}$ & $\begin{array}{c}0.310^{* * *} \\
(0.050)\end{array}$ \\
\hline FDI & $\begin{array}{c}0.417^{* * *} \\
(0.100)\end{array}$ & $\begin{array}{c}0.202^{* * *} \\
(0.054)\end{array}$ \\
\hline Trade & $\begin{array}{c}-0.084 \\
(0.069)\end{array}$ & $\begin{array}{c}-0.009^{* *} \\
(0.032)\end{array}$ \\
\hline$F$-test & 44.65 & \\
\hline LM test & & 0.22 \\
\hline$R^{2}$ within & 0.24 & \\
\hline$R^{2}$ between & 0.05 & \\
\hline$R^{2}$ overall & 0.11 & \\
\hline No. of obs. & 168 & 168 \\
\hline No. of country & 8 & 8 \\
\hline
\end{tabular}

Lastly, trade has a negative sign and is only significant in the random effects. The weak evidence of the relationship between trade openness and income growth may be attributed to the presence of trade creation and trade diversion (Viner, 1950). If the effect of trade diversion in the region is bigger than trade creation, trade openness will not result in output growth.

The F-test of the fixed effects strongly rejects the null, justifying the presence of a correlation between the explanatory variables and heterogeneous effects in errors. In other words, the fixed effects estimation provides unbiased and consistent estimators. On the other hand, the Breusch-Pagan Lagrange Multiplier test for random effects is not significant at $10 \%$ level, failing to reject the null of individual effects are equal, i.e. there are no random effects. As the consequence, the random effects estimation is biased and inconsistent.

\section{Economic Growth and Financial Crises}

Next, the discussion of this paper moves to the impact of financial crises on economic growth in East Asian economies. As shown in the methodology, this paper employs crisis 
dummy in order to measure the impacts of financial crises on East Asian economies. The first crisis dummy is for the 1997 East Asian Financial Crisis. In this regard, even though the crisis struck in 1997, the dummy variable takes the value of unity in 1997-1998 by considering the lagging effect of the crisis. The second one is for the 2008 Global Financial Crisis. Similarly, since the lagging effect also exists, the crisis dummy is assigned in the year when the crisis struck and the following year, i.e.2008-2009.

Table 2 presents the benchmark growth model that is augmented by the crisis dummies. In the first two columns, it is augmented with the 1997 East Asian Financial crisis. In general, the relationship between growth determinants and income growth is consistent with the initial benchmark regression.Next, as expected, the crisis dummy is significant in both models with relatively similar magnitude. According to the estimation, under ceteris paribus, the presence of East Asian Financial crisis causes East Asian economies to experience negative income growth of around $6 \%$.

\begin{tabular}{|c|c|c|c|c|}
\hline \multicolumn{5}{|c|}{$\begin{array}{c}\text { Table } 2 . \\
\text { Economic Growth and Financial Crises }\end{array}$} \\
\hline Variables & Fixed Effects & Random Effects & Fixed Effects & Random effects \\
\hline Constant & $\begin{array}{l}-7.970 \\
(6.816)\end{array}$ & $\begin{array}{l}-0.435 \\
(1.921)\end{array}$ & $\begin{array}{l}-24.975^{\star *} \\
(10.310)\end{array}$ & $\begin{array}{l}-1.071 \\
(2.104)\end{array}$ \\
\hline Income & $\begin{array}{c}0.621 \\
(1.957)\end{array}$ & $\begin{array}{l}-1.359^{* \star *} \\
(0.422)\end{array}$ & $\begin{array}{l}6.491^{*} \\
(3.270)\end{array}$ & $\begin{array}{l}-1.223^{\star \star *} \\
(0.405)\end{array}$ \\
\hline Capital & $\begin{array}{l}0.295^{\star * *} \\
(0.051)\end{array}$ & $\begin{array}{l}0.311^{* * *} \\
(0.037)\end{array}$ & $\begin{array}{l}0.180^{*} \\
(0.085)\end{array}$ & $\begin{array}{l}0.307^{* * *} \\
(0.054)\end{array}$ \\
\hline FDI & $\begin{array}{l}0.428^{* * *} \\
(0.060)\end{array}$ & $\begin{array}{l}0.210^{\star \star *} \\
(0.042)\end{array}$ & $\begin{array}{l}0.328^{* *} \\
(0.104)\end{array}$ & $\begin{array}{l}0.171^{* * *} \\
(0.041)\end{array}$ \\
\hline Trade & $\begin{array}{l}0.018 \\
(0.049)\end{array}$ & $\begin{array}{c}0.001 \\
(0.017)\end{array}$ & $\begin{array}{l}-0.119 \\
(0.079)\end{array}$ & $\begin{array}{l}0.004 \\
(0.028)\end{array}$ \\
\hline Asia Crisis & $\begin{array}{l}-5.944^{* * *} \\
(1.385)\end{array}$ & $\begin{array}{l}-5.988^{* * *} \\
(1.304)\end{array}$ & - & - \\
\hline Global Crisis & - & - & $\begin{array}{l}-3.014^{* *} \\
(0.945)\end{array}$ & $\begin{array}{l}-2.128^{* *} \\
(0.879)\end{array}$ \\
\hline$F$-test & 219.49 & & 89.48 & \\
\hline LM test & & 0.00 & & 0.21 \\
\hline$R^{2}$ within & 0.47 & & 0.296 & \\
\hline$R^{2}$ between & 0.40 & & 0.016 & \\
\hline$R^{2}$ overall & 0.42 & & 0.020 & \\
\hline No. ofobs. & 168 & 168 & 168 & 168 \\
\hline No. of country & 8 & 8 & 8 & 8 \\
\hline
\end{tabular}


Once again, this paper tests which of these estimation methods provides better estimation by looking at the F-test (for fixed effects) and LM test (for random effects). Similar to the benchmark regression output, $F$-test significantly rejects the null at $1 \%$ level, whereas LM test fails to reject the null at 10\% level. Thus, in the East Asian Financial Crisis, fixed effects estimation is the better model since it provides consistent and unbiased estimators.

The last two columns exhibit the benchmark growth model with 2008 Global Financial crisis. Surprisingly, the fixed effects model shows that the magnitude of income becomes higher if the model is controlled for 2008 crisis, implying that countries with higher income tend to grow faster even though the evidence is very weak (i.e. only significant at $10 \%$ level of confidence). One possible explanation is because countries with relatively higher income, particularly Singapore, managed to attain income growth beyond $10 \%$ after the crisis even though it recorded negative growth when the crisis struck, whereas countries with relatively lower income such as Indonesia only achieved stable growth despite the fact that it successfully avoided negative growth when the crisis struck.

On the other hand, other variables, i.e. capital, FDI and trade, do not differ significantly from the previous estimations. Finally, the Global Financial Crisis dummy is significant at $5 \%$ in both regressions even though the impact of the crisis is higher in the fixed effects model. Furthermore, the result is also consistent with the expectation of this paper, i.e. the 2008 Global Financial Crisis has smaller adverse impact on income growth in East Asian economies.

\section{Further Discussion and Analysis}

Other than the coefficients for income and trade, estimation results of the model are inline with expectations and consistent with previous studies. The objective of this section, thus, is to provide further discussion and analysis on the estimation results. First, the coefficients for income in the benchmark model as well as the models augmented by the 1997 East Asian Crisis dummy show insignificant results with signs that are not inline with expectations. However, the estimation result from the model augmented by the 2008 Global Financial Crisis dummy is significant at $10 \%$ level of significance and similar with previous case it is not of expected sign. These results indicate that the growth model used in this paper only weakly support Solow's (1956) neo-classical growth theory, particularly that that is relating to economic convergence.

Second, all of the estimated coefficients for capital are significant and positive which is as expected. This shows that capital accumulation is indeed leading to economic growth. However, estimation results for FDI, which are more significant than those for capital, indicate the presence of knowledge transfer from the more developed economies to the less developed one through FDI. These results support the studies conducted by Lim (2001) and Yao and Wei (2007), which suggest that FDI facilitates externalities and spillover effects that will enhance efficiency of productivity of local firms. In turn, these will support economic growth. 
Third, all of the estimated coefficients for trade are insignificant and of conflicting signs, which suggest that the model provides insufficient evidence for us to make any inference about the correlation between trade openness and income growth. Nevertheless, these results indicate that the data used in this paper support the study of Chongvilaivan (2010), whose paper proposes the insignificance of trade variable as the result from the presence of trade creation or trade diversion. Therefore, the effect of trade on income growth depends on whether the welfare of trade alliance's members is increasing at the expense of non-members or not.

Lastly, even though both of the estimation results for crisis dummies show negative sign, the 1997 East Asian Crisis dummy shows higher magnitude compared to the 2008 Global Financial Crisis dummy. This is in accordance with expectation since the 1997 East Asian Crisis was happening in the East Asian region and was a result from causes internal to the region, including: 1) lack of policy credibility and 2) inadequate financial infrastructure that accompanied financial deregulations.For the former, as argued by Raisah (2001), this crisis was initially triggered by abusive state intervention and less effective industrial policies in the region. As for the latter, financial deregulations inadequate financial infrastructure and poor banking supervision encouraged risky investments without sufficient risk assessment led the credit bubble and collapse of the financial sector (for instance, see Radelet and Sachs, 2000). These weak economic fundamentals reflect the "financial fragility" as the main issue of East Asian economies, which triggered the crisis in 1997 and hit the region's economy severely (see Appendix 5 for statistics on macroeconomic variables during both financial crises). Further, this crisis was deepened due to its spread to the real sector, which hurt the borrower's business and, massive capital outflow.

On the other hand, the crisis in 2008 had smaller impacts on the region's economy since the region only suffered the "contagious effect" of the crisis that was actually originated in the developed economies. To some extent, this result supportspaper, which suggests that the divergence may relate to the externality of the 2008 Global Financial crisis (Chongvilaivan, 2010; Emmers and Ravenhill, 2011). Nevertheless, indeed the improvements in the fundamentals of East Asian economies prior to 2008 Global Financial Crisis werealso much attributed to the multidimensional reforms that followed 1997 East Asian Financial Crisis. To be more specific,Goldstein and Xie (2009) point out that large holdings of foreign reserves, improved financial structure, high share of regional trade, and stances toward countercyclical monetary and fiscal policies would assist the region to weather negative impacts from the crisis.

\section{CONLUSIONS}

World's financial system, reinforced by development in information technology, has strengthened financial integration between countries around the world. Despite the advantages of this advancement, however, financial integration has also caused financial crises to spread more easily and rapidly, undermining connected economies. Due to this reason,studies about financial crises have become more important than ever since. In this regard, the objective of 
this study is to better understandthe causes and consequences of the recent financial crises by providing comprehensive analysis in order to prevent the occurrence, or at least minimize the impact, of financial crisis in the future.

This study has revealed important findings about the main impacts of financial crises on East Asian economies. First, this study has investigated the impact of both 1997 East Asian Financial Crisis and 2008 Global Financial Crisis by using a quantitative approach, i.e. panel regression. The result shows that even though both crises had adverse effects on the economy of the region, East Asian economies had become more resilient during the crisis in 2008 compared to that in 1997. Further, this paper finds out that minimized impact of the crisis in 2008 occurred since, in addition to the "externality" of the crisis, most East Asian economies had learned its lesson after the 1997 East Asian Financial Crisis by strengthening economic fundamentals, underpinned further better government credibility and accountability.

Concerted efforts to restructure the banking and financial sectorby East Asian governments that follows the 1997 East Asian Financial Crisis had increased resilience to economic crises. Included in the reforms was better supervision on this sector as opposed to period prior deregulations and suspensions as well as merging troubled financial institutions. Capital was also injected to assist with liquidity problem. Apart from banking and financial sector reform, higher requirement for corporate transparency was also demanded to increase credibility of the private sectors. Altogether, these reforms had strengthened economic fundamentals of East Asian countries. Another most important things that had better preparedEast Asian countries in facing the 2008 Global Financial Crisis was improvement in foreign exchange reserves condition, which aiding governments in defending the economy during the crisis.

Despite its findings, the scope of this study is limited to country-level data and analysis. Hence, further studies should focus more on the industry-level analysis and thus have to be facilitated by the availability of industry-level data in order examine the sensitivity of each industry in anticipating the financial crises. In addition, the estimation results in this study can be improved by adding interaction variables between crisis dummy and other independent variables as well as introducing the GMM estimation in estimating the model in order to capture the simultaneous equations in the model. 


\section{REFERENCES}

Asian Development Bank (ADB). (1999). Asian Development Outlook 1999, Manila: Asian Development Bank.

Azman-Saini, W.N.W., Law, S.H., \& Ahmad, A.H. (2010). FDI and economic growth: New evidence on the role of financial markets, Economic Letters, Vol. 107, pp. 211-213.

Barro, R.J. (2001). Economic growth in East Asia before and after the Financial Crisis, National Bureau of Economic Research Working Paper Series, No. 8330.

Bhagwati, J. (1994). Free trade: Old and new challenges, Economic Journal, Vol. 104, pp. 231246.

Chongvilaivan, A. (2010). Global Financial Crisis and growth prospects in Asia-Pacific: A sectoral analysis, paper presented at The $26^{\text {th }}$ Conference of the American Committee for Asian Economic Studies, Kyoto, Japan, 5-6 March.

Corsetti, G., Pesenti, P., \&Roubini, N. (1999). What caused the Asian currency and financial crisis? Japan and the World Economy, Vol. 11, pp. 305-373.

Davis, E.P. (1994). Market liquidity risk,Kluwer Academic Publishers.

Davis, E.P. (2001). A typology of financial instability, Oesterreichsche National Bank Financial Stability Report 2, pp. 92-110.

Diamond, D., Dybvig, P. (1983). Bank runs, deposit insurance and liquidity, Journal of Political Economy, Vol. 91, pp. 401-419.

Edison, H.J., Levine. R., Ricci, L., \&Sløk, T. (2002).International financial integration and economic growth, National Bureau of Economic Research Working Paper Series, No. 9164.

Emmers, R., Ravenhill, J. (2011), The Asian and global financial crises: consequences for East Asian regionalism, Contemporary Politics, Vol.17 no. 2, pp. 133-149

Fisher, I. (1933). The debt deflation theory of great depressions, Econometrica, Vol.1, pp. 337357.

Goldstein, M., \&Xie, D. (2009). US credit crisis and spillovers to Asia, Asian Economic Policy Review, vol. 4, pp. 204-222. 
Hadri, K.(2000). Testing for stationarity in heterogeneous panel data, The Econometrics Journal, Vol. 3, no. 2, pp. 148-161.

Herring, J. (1999). Credit risk and financial instability, Oxford Review of Economic Policy, vol. 15, No. 3, pp. 63-67.

Im, K.S., Pesaran, M. H. \& Shin, Y. (2003). Testing for unit roots in heterogeneous panels, Journal of Econometrics, Vol. 115, pp. 53-74.

Jomo, K.S. (2001). Growth after the Asian Crisis: What remains of the East Asian Model?, G-24 Discussion Paper Series, No. 10.

Kawai, M., Newfarmer, R., \& Schmukler, S. L. (2003). Financial crises: Nine Lessons from Asia, Japan Ministry of Finance PRI Discussion Paper, No. 2003-5.

Khor, M. (1998). The economic crisis in East Asia: Causes, effects, lessons, Third World Network.

Kindleberger, C. P. (1978). Manias, panics and crashes, A history of financial crises. Basic Books, New York.

Levin, A., Lin, C.F. \& Chu, C. (2002). Unit roots tests in panel data: Asymptotic and finite sample properties, Journal of Econometrics, Vol. 108, pp. 1-24.

Lim, E.G. (2001).Determinants of, and the relation between, foreign direct investment and growth: A summary of the recent literature, IMF Working Paper, WP/01/175.

Lloyd, P.J., \& MacLaren, D. (2000). Openness and growth in East Asia after the Asian crisis, Journal of Asian Economics, Vol. 11, pp. 89-105.

Lucas, R.E. (1988). On the mechanism of economic development, Journal of Monetary Economics, vol.22, pp. 3-42.

Rasiah, R. (2001). Pre-crisis economic weaknesses and vulnerabilities. In: Jomo KS, ed. Malaysian Eclipse: Economic Crisis and Recovery, London: Zed Books, pp. 47-66.

Radelet, S. and Sachs, J. (2000). The onset of East Asian financial crisis, National Bureau of Economic Research, pp. 105-162.

Research Bank of Australia. (2012). About financial stability. Retrieved from http:// www.rba.gov.au/fin-stability/about.html on 7 December 2012.

Romer, P.M. (1986). Increasing return and long run growth, Journal of Political Economy, vol. 95, pp. 1002-1037.

(1990). Endogenous technological change, Journal of Political Economy, vol 98, no. 5, pt. 2.

Siegel, D. (1997). The impact of computers on manufacturing productivity growth: A multipleindicators, multiple-causes approach, Review of Economics and Statistics, vol. 79, pp. 68-78. 
Siegel, D. \& Griliches, Z. (1992). Purchased services, outsourcing, computers, and productivity in manufacturing, National Bureau of Economic Research Working Paper Series, No. 3678.

Solow, R.M. (1956).A contribution to the theory of economic growth, Quarterly Journal of Economics, LXX, pp. 65-94.

Stopford, J., Strange, S., \&Henley, J. (1991). Rival States, Rival Firms: Competition for World Market Shares, Cambridge: Cambridge University Press.

Todaro, M. P, \& Smith, S. C. (2006). Economic Development, Addison Wesley, Boston.

Viner, J. (1950). The Custom Union Issue, New York: Carnegie Endowment for International Peace.

World Bank. (various issues). World Bank Indicator (http://data.worldbank.org/indicator/)

Yao, S. \& Wei, K. (2007). Economic growth in the presence of FDI: The perspective of newly industrialising economies, Journal of Comparative Economics, Vol. 35, pp. 211-234. 


\section{APPENDICES}

\begin{tabular}{|c|c|}
\hline \multicolumn{2}{|r|}{$\begin{array}{l}\text { Appendix } 1 . \\
\text { Variable Descriptions }\end{array}$} \\
\hline Variable & Description \\
\hline Growth & $\begin{array}{l}\text { Annual percentage growth rate of GDP per capita based on constant local currency. GDP per } \\
\text { capita is gross domestic product divided by midyear population. GDP at purchaser's prices } \\
\text { is the sum of gross value added by all resident producers in the economy plus any product } \\
\text { taxes and minus any subsidies not included in the value of the products. It is calculated } \\
\text { without making deductions for depreciation of fabricated assets or for depletion and degradation } \\
\text { of natural resources. (Expressed in \%) }\end{array}$ \\
\hline Income & $\begin{array}{l}\text { GDP per capita is gross domestic product divided by midyear population. GDP is the sum } \\
\text { of gross value added by all resident producers in the economy plus any product taxes and } \\
\text { minus any subsidies not included in the value of the products. It is calculated without making } \\
\text { deductions for depreciation of fabricated assets or for depletion and degradation of natural } \\
\text { resources. (Expressed in constant U.S. dollars) }\end{array}$ \\
\hline Capital & $\begin{array}{l}\text { Gross capital formation (formerly gross domestic investment) consists of outlays on additions } \\
\text { to the fixed assets of the economy plus net changes in the level of inventories. Fixed assets } \\
\text { include land improvements (fences, ditches, drains, and so on); plant, machinery, and } \\
\text { equipment purchases; and the construction of roads, railways, and the like, including schools, } \\
\text { offices, hospitals, private residential dwellings, and commercial and industrial buildings. } \\
\text { Inventories are stocks of goods held by firms to meet temporary or unexpected fluctuations } \\
\text { in production or sales, and "work in progress." According to the } 1993 \text { SNA, net acquisitions } \\
\text { of valuables are also considered capital formation. (Expressed in \% of GDP) }\end{array}$ \\
\hline$F D I$ & $\begin{array}{l}\text { Foreign direct investment are the net inflows of investment to acquire a lasting management } \\
\text { interest ( } 10 \text { percent or more of voting stock) in an enterprise operating in an economy other } \\
\text { than that of the investor. It is the sum of equity capital, reinvestment of earnings, other long- } \\
\text { term capital, and short-term capital as shown in the balance of payments. (Expressed in \% } \\
\text { of GDP) }\end{array}$ \\
\hline Trade Openness & The the ratio of exports and imports to GDP (Expressed in \% of GDP) \\
\hline Crisis & $\begin{array}{l}\text { A dummy variable to represent the occurrence of crisis (whether } 1997 \text { East Asian Financial } \\
\text { Crisis or } 2008 \text { Global Financial Crisis). It takes the value of unity during the crisis and nil } \\
\text { during the non-crisis period). }\end{array}$ \\
\hline
\end{tabular}

\begin{tabular}{|l|c|c|c|c|c|}
\multicolumn{7}{|c|}{ Appendix 2. } \\
\multicolumn{1}{|c|}{ Summary Statistics (Period: 1990-2010) } \\
\multicolumn{1}{|c|}{ Variable } & Obs. & Mean & S.D. & Min & Max \\
\hline Growth & 357 & 2.843 & 3.567 & 14.287 & 13.605 \\
Income & 357 & 3.864 & 0.644 & 2.486 & 4.610 \\
Capital & 357 & 24.875 & 7.465 & 11.367 & 48.243 \\
FDI & 357 & 2.900 & 3.672 & 5.112 & 22.018 \\
Trade Openness & 357 & 2.583 & 7.011 & 10.337 & 32.266 \\
\end{tabular}


Appendix 3.

Correlation Matrix of Independent Variables

\begin{tabular}{l|c|c|c|c} 
& Income & Capital & FDI & Trade Openness \\
Income & 1.000 & & & \\
Capital & 0.166 & 1.000 & & \\
FDI & 0.391 & 0.117 & 1.000 & \\
Trade Openness & 0.132 & 0.530 & 0.028 & 1.000
\end{tabular}

\begin{tabular}{|c|c|c|c|}
\hline \multicolumn{4}{|c|}{$\begin{array}{c}\text { Appendix } 4 . \\
\text { Levin Lin Chu test for panel unit root }\end{array}$} \\
\hline Variable & t-star & t-value & p-vale \\
\hline Growth & 8.871 & 4.869 & 0.000 \\
\hline Income & 7.941 & 2.717 & 0.003 \\
\hline Capital & 7.543 & 2.456 & 0.007 \\
\hline$F D I$ & 10.362 & 4.292 & 0.000 \\
\hline Trade Openness & 7.086 & 2.295 & 0.011 \\
\hline
\end{tabular}




\section{APPENDIX 5. OTHER MACROECONOMIC STATISTICS}

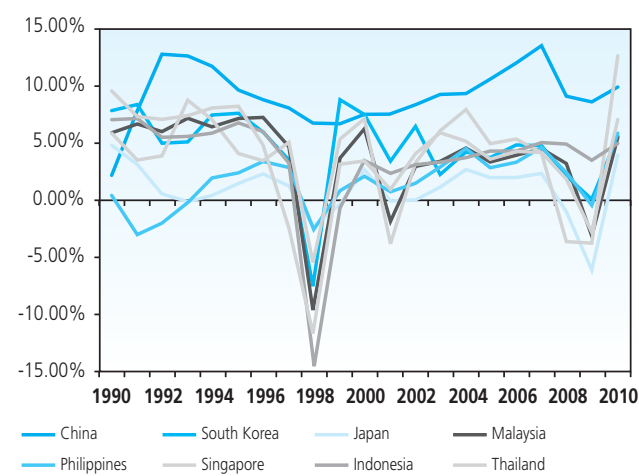

Source : World Bank's World Development Indicator

Appendix 5.1.

GDP percapita in East Asian economies (annual growth rate, \%)

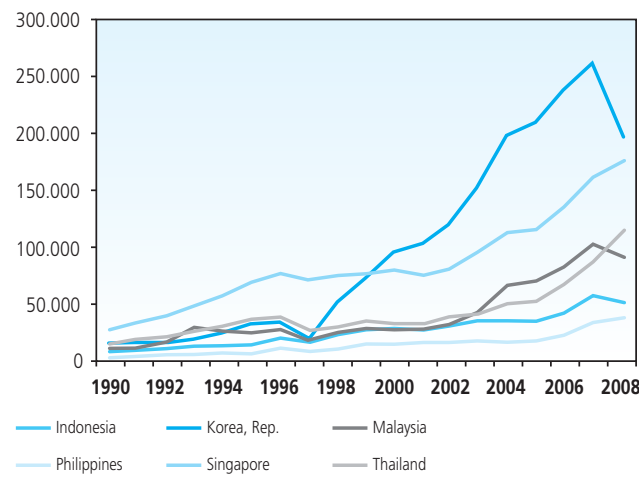

Source : World Bank's World Development Indicator and Global Development Finance.

Appendix 5.2.

Foreign exchange reserves of several East Asian countries (in million) 


\begin{tabular}{l|c|c}
\multicolumn{2}{c}{$\begin{array}{c}\text { Appendix 5.3. } \\
\text { Inflation rate in Asian Economies, 1997-1998 }\end{array}$} \\
\cline { 2 - 3 } & 1997 & 1998 \\
\cline { 2 - 3 } Inflation \\
\hline China & 2.8 & -0.8 \\
\hline Indonesia & 6.2 & 58.4 \\
\hline Japan & 1.8 & 0.7 \\
\hline Malaysia & 2.7 & 5.3 \\
\hline Philippines & 5.6 & 9.3 \\
\hline Singapore & 2 & -0.3 \\
\hline South Korea & 4.4 & 7.5 \\
\hline Thailand & 5.6 & 8.0 \\
\hline Source: World Bank's World Development Indicator
\end{tabular}

\begin{tabular}{|c|c|c|c|c|c|c|c|c|c|c|}
\hline \multicolumn{11}{|c|}{$\begin{array}{l}\text { Appendix 5.4. } \\
\text { East Asia Four: Macroeconomic indicators, 1990-1999 }\end{array}$} \\
\hline & \multicolumn{5}{|c|}{ Unemployment Rate } & \multicolumn{5}{|c|}{ Savings/GDP } \\
\hline & 1990 & 1996 & 1997 & 1998 & 1999 & $1990-95$ & 1996 & 1997 & 1998 & 1999 \\
\hline Indonesia & n.a. & 4.1 & 4.6 & 5.5 & 6.3 & 31 & 26.2 & 26.4 & 26.1 & 23.7 \\
\hline Malaysia & 6 & 2.5 & 2.4 & 3.2 & 3 & 36.6 & 37.1 & 37.3 & 39.6 & 38 \\
\hline Rep. of Korea & 2.4 & 3 & 2.6 & 6.8 & 6.3 & 35.6 & 33.7 & 33.3 & 33.8 & 33.5 \\
\hline \multirow[t]{3}{*}{ Thailand } & 4.9 & 1.1 & 0.9 & 3.5 & 4.1 & 34.4 & 33 & 32.5 & 34.9 & 31 \\
\hline & \multicolumn{5}{|c|}{ Investment/GDP } & \multicolumn{5}{|c|}{ (Savings-investment)/GDP } \\
\hline & $1990-95$ & 1996 & 1997 & 1998 & 1999 & $1990-95$ & 1996 & 1997 & 1998 & 1999 \\
\hline Indonesia & 31.3 & 29.6 & 28.7 & 22.1 & 19.3 & -0.3 & -3.4 & -2.3 & 4 & 4.4 \\
\hline Malaysia & 37.5 & 42.5 & 43.1 & 26.8 & 22.3 & -0.9 & -5.4 & -5.8 & 12.8 & 15.7 \\
\hline Rep. of Korea & 36.8 & 36.8 & 35.1 & 29.8 & 28 & -1.2 & -3.1 & -1.8 & 4.1 & 5.5 \\
\hline \multirow[t]{3}{*}{ Thailand } & 41 & 41.1 & 33.3 & 22.2 & 21 & -5.6 & -8.1 & -0.9 & 12.8 & 10 \\
\hline & \multicolumn{5}{|c|}{ Incremental capital-output rations } & & & & & \\
\hline & $1987-89$ & $1990-92$ & 1993-95 & 1997 & 1998 & 1999 & & & & \\
\hline Indonesia & 4 & 3.9 & 4.4 & 1.7 & 0.4 & 1.8 & & & & \\
\hline Malaysia & 3.6 & 4.4 & 5 & 3.9 & 28.2 & 4.3 & & & & \\
\hline Rep. of Korea & 3.5 & 5.1 & 5.1 & 4.2 & -15.1 & 3.2 & & & & \\
\hline \multirow[t]{3}{*}{ Thailand } & 2.9 & 4.6 & 5.2 & 12.9 & -11.5 & 14.5 & & & & \\
\hline & \multicolumn{5}{|c|}{ Fiscal balance/GDP } & & & & & \\
\hline & $1990-95$ & 1996 & 1997 & 1998 & 1999 & & & & & \\
\hline Indonesia & 0.2 & 1.4 & 1.3 & -2.6 & -3.4 & & & & & \\
\hline Malaysia & -0.4 & 0.7 & 2.4 & -1.8 & -3.2 & & & & & \\
\hline Rep. of Korea & 0.2 & 0.5 & -1.4 & -4.2 & -2.9 & & & & & \\
\hline Thailand & 3.2 & 2.4 & -0.9 & -3.4 & -3 & & & & & \\
\hline Source: & d Sachs & $\begin{array}{l}\text { 1998: ta } \\
\text { ara Mala }\end{array}$ & ble 11): & $\begin{array}{l}(1999) \\
\text { from JC }\end{array}$ & $\begin{array}{l}\text { Bank of } \\
\text { רo }(2011\end{array}$ & Thailand, & $\mathrm{k} \ln$ & Bank & & \\
\hline
\end{tabular}


This page is intentionally left blank 